Original Research

\title{
Construction of a Niche-Fitness Model for Well-Facilitated Capital Farmland and its Application
}

\author{
Suxia Zhao, Haipeng Niu*, Hebing Zhang
}

Department of Surveying and Land Information Engineering, Henan Polytechnic University, Jiaozuo, Henan, China

Received: 16 October 2017

Accepted: 25 December 2017

\begin{abstract}
Today, constructing well-facilitated capital farmland on a large scale is one of the key strategic initiatives for enhancing the national capacity for food security. In order to strengthen the scientific and rational distribution of well-facilitated capital farmland, this article, starting with the discussion of ecosystem integrity of regional well-facilitated capital farmland on the basis of ecological niche theory, proposes the concept of ecological niche for well-facilitated capital farmland, and constructs "ecostate" and "ecorole" evaluation models $\left(\mathrm{N}_{\mathrm{i}}\right.$ model) of ecological niche for well-facilitated capital farmland. This is verified by studying the case of the city of Xinzheng, Henan Province, China. As the research result shows, first the condition of farmland in Xinzheng is generally good, and the farmland in the whole city is suitable for the construction of well-facilitated capital farmland covering $34,224.48 \mathrm{hm}^{2}, 63.18 \%$ of the total area, which is mainly distributed in the southern and northwestern parts of the city. Second, the evaluation results are generally in consistency with the actual situation, which indicates that the $\mathrm{N}_{\mathrm{i}}$ model is scientific and realistic in the evaluation of suitability for constructing well-facilitated capital farmland. Meanwhile, the $\mathrm{N}_{\mathrm{i}}$ values are helpful for indicating the suitability for regional well-facilitated capital farmland. Third, using the most suitable ecological niche to explain standards of construction for well-facilitated capital farmland, and matching $n$ dimension resources ecological niche along with most suitable ecological niche to evaluate well-facilitated capital farmland will convey clear ecological significance and be quite helpful to develop plans and measures for constructing well-facilitated capital farmland based on the size and changes of niche-fitness values.
\end{abstract}

Keywords: ecological niche, well-facilitated capital farmland, evaluation model, niche ecostate-ecorole theory

*e-mail: niuhaipeng1974@126.com 


\section{Introduction}

According to the document The Well-Facilitated Capital Farmland Construction Standards (TD/T 10332012), issued by the Ministry of Land and Resources, well-facilitated capital farmland construction is defined as the formation, through reorganization and management of rural land, of concentrated areas of farmland with good facilities, high and stable yield, good ecology, and a capacity for resisting natural disasters, which are adapted to modern agricultural production and mode of operation of capital farmland. Construction of well-facilitated capital farmland is an innovation of the farmland protection system under the new situation, and is also an essential approach to realize that the farmland protection system changes from quantity-centered to quantity and quality being equally valued. With accelerated industrialization and urbanization, as well as the everincreasing population and adjustment and upgrading of consumption levels, China's grain consumption demand will still grow steadily. Due to the large fluctuations in the international grain market and limitations in regulating domestic grain surplus, food security must be based on the domestic situation. However, constructions in the current process of urbanization have taken up plenty of high-quality farmland around cities, and the complementary farmland is mainly distributed in the areas with poor terrain conditions and low-quality land. In addition, farmland is improperly used and maintained, in the result of excessive inputs of chemical fertilizers and pesticides in agriculture, growing soil acidification, and intensified land degradation. China is now facing an overall decline in quality of farmland, and the problem of food security has become increasingly prominent. Therefore, when the area of farmland is not able to be enlarged, increased demand for food may have to rely on increasing food production capacity. Consequently, to reorganize and manage rural land and to construct well-facilitated capital farmland with stable yield are of great strategic significance for strengthening China's food security, enhancing agricultural modernization, and improving quality, quantity, and ecological management of farmland.

With the advancement of our well-facilitated capital farmland construction work, blind construction has brought about some problems in which agriculturerelated funds are not properly used in reorganization and management of farmland resources, and that the capital investment is too decentralized. Therefore, how to select sites, construct and use funds properly in accordance with the well-facilitated capital farmland construction standards is a serious problem in many regions.

At present, well-facilitated capital farmland construction work is being carried out in many parts of China. Although many successful experiences in the process of construction have accumulated, there are still a number of problems, one of which is the selection of sites of well-facilitated capital farmland construction. Chinese scholars have done a lot of research in terms of the relevant theories and policies [1-2], of assessment approaches [3-4], of farmland construction patterns, and scheduling [5-6]. However, there is no adequate research from the overall regional perspective, particularly from the point of view of landscape ecology, and hence ignoring the ecological value of capital farmland. Therefore, our paper is devoted to introducing the niche-fitness evaluation model, which contains clear ecological meaning, into research of well-facilitated capital farmland construction. The purpose is that properties of the comprehensive ecological system integrating nature, economy, and society may get explained and measured by using ecological theory. Besides, the subjectivity in traditional evaluation processes can be reduced by integrating research of well-facilitated capital farmland construction into a system for the purpose of laying down the land regulation planning scientifically, improving the efficiency of well-facilitated capital farmland construction, and strongly promoting rural land management.

\section{Material and Methods}

\section{Study Area}

Xinzheng is located in the heart of the Central Plains, with the center of the provincial capital Zhengzhou to the north, Zhongmou and Weishi to the east, Xinmi to the west, and Changge and Yuzhou to the south, it is one of the parts of greater Zhengzhou. The geographical position is $34^{\circ} 16^{\prime} \sim 34^{\circ} 39^{\prime} \mathrm{N}$, $113^{\circ} 30^{\prime} \sim 113^{\circ} 54^{\prime} \mathrm{E}$, which covers $42 \mathrm{~km}$ from north to south and $36 \mathrm{~km}$ from east to west, with total area of $884.59 \mathrm{hm}^{2}$. Xinzheng city consists of 3 small towns, 9 big towns, and 3 urban neighborhood offices. The Shuangpo River runs more than $30 \mathrm{~km}$ through the city. The annual average temperature reaches $14.3^{\circ} \mathrm{C}$, with annual average rainfall of $735 \mathrm{~mm}$ and a frost-free period of 208 days each year. The western part of Xinzheng is high in terrain while low in the eastern part, and high in the middle while low in the southern and northern parts. There are various types of terrain, including mountains, hills, hillocks, and plains. Soil is divided into 3 types: cinnamon, moist, and sand-drift soil. According to the survey of changes of land use in Xinzheng 2013, the city has a total area of farmland of $51,824.93 \mathrm{hm}^{2}$, covering $58.59 \%$ of the city's total land area (Fig. 1).

\section{Data Source and Processing}

The main data used in this paper is the investigation database of changes of land use in 2013, overall landuse planning in Xinzheng (2010-2020), the updated results of quality grades of farmland in Xinzheng (2012), the multi-purpose geochemical survey, the ecological land information of typical regions in the Central Plains Economic Zone and fine assessment results (2014), the Statistical Yearbook of Xinzheng (2013), and so on. 


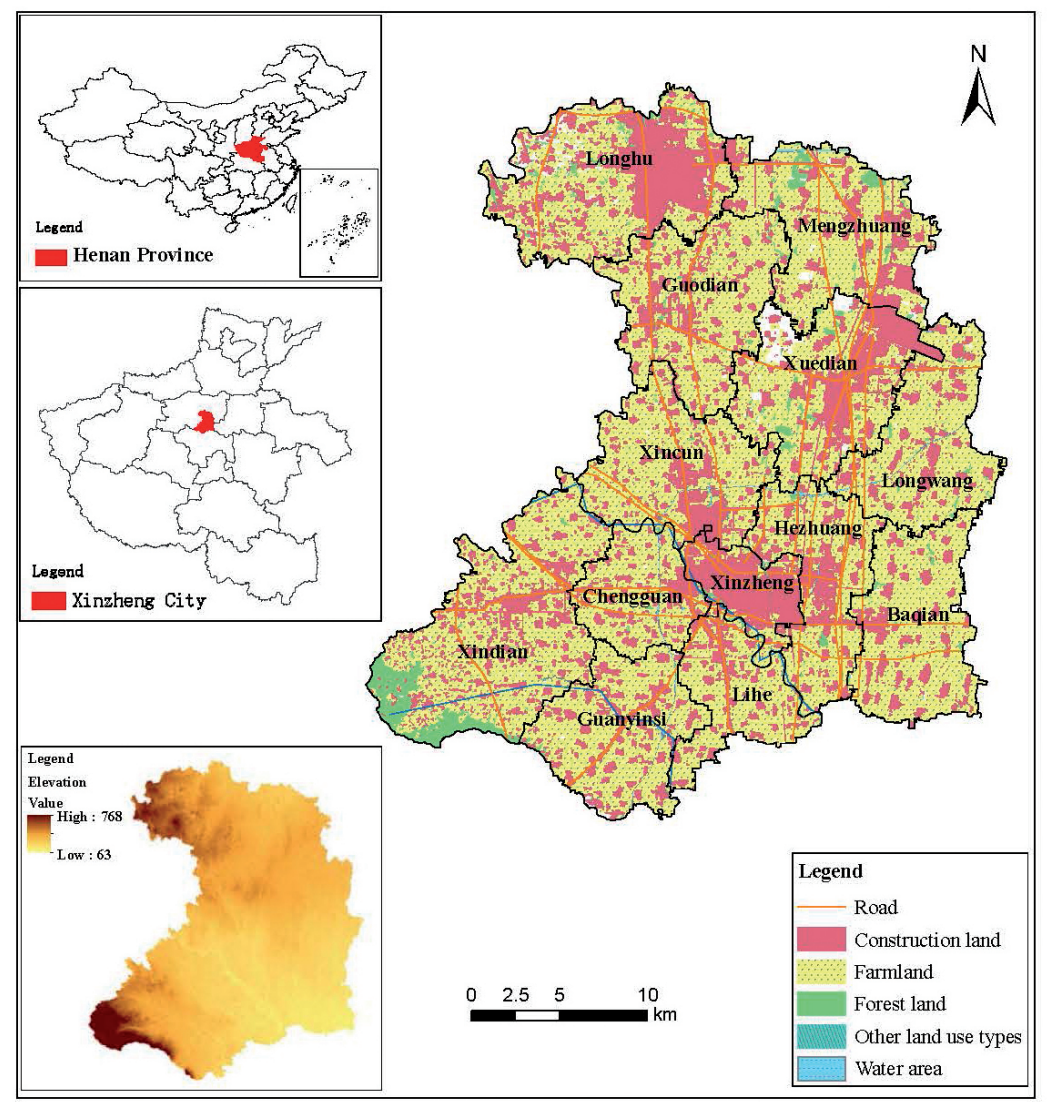

Fig. 1. Location of the Study Area.

Data about soil texture, effective soil thickness, soil organic matter content, and $\mathrm{pH}$ value are obtained on the basis of sampling data of field survey in typical areas, combined with the base data and soil maps and other relevant information in the agricultural sector; the slope data is extracted according to DEM in Xinzheng; the soil pollution level is determined by the content of heavy metal pollutants in soil such as chromium, cadmium, lead, copper, zinc, and non-metallic pollutants like arsenic and chemical fertilizer nitrogen and ammonium-nitrogen. The N. L. Nemerow index is used to calculate integrated pollution index of soil; concentrated degree of farmland is the plot's reasonable connectivity in space, and it is calculated by adopting the method of GIS, this article mixed the facts of the situation of local agricultural road of production, ditch, and hydraulic structures to select plot spot of farmland, assuming that plots with separate spaces of less than $5 \mathrm{~m}$ are connected [7-8], and that the buffer zone is also analyzed; field road accessibility is represented by the distance from field plots to rural roads, and the shortest distance can be calculated by the tool near ARCGIS; drainage and irrigation guarantee rate are determined by the distribution of irrigation canals in Xinzheng and irrigation areas effectively covered by wells, and at the same time the distribution map of farmland irrigation and drainage of Xinzheng should be worked out based on field surveys.

\section{Defining the Ecological Niche of Well-Facilitated Capital Farmland}

Ecological niche is a very important concept in the field of ecology. In 1924 Grinell created the ecological niche concept [9]. Since then, Elton [10], Hutchinson [11], Whittaker [12], Odum [13], and Leibold[14] have extended the concept of ecological niche, and connotations and denotations of the ecological niche theory have been constantly enlarged and deepened. The Chinese scholar Li Zizhen and others have put forward the concept of niche fitness on the basis of the existing ecological niche theory [15]. Zhu Chunquan and others have proposed the niche ecostate-ecorole theory and its extension hypothesis of [16]. During past years, researchers on ecological niche theory have been going further and more and more closely associated with research of land resources. For instance, Zhang et al. [17] introduced ecological niche as a new method of study of land utilization or covering. Wang et al. [18] constructed an ecological niche-fitness model for various ways of using land, and exploited a new approach for the quantitative analysis of effects of land use on environmental vulnerability. Wang et al. [19] optimized the quantity structure of land resources by using the ecological model. Li et al. [20] constructed a cellular automata model of ecological niche fitness for suitability evaluation of land development and construction. Niu et al. [21] defined the concepts of 
"ecological unit of farmland" and "ecological niche of farmland," and constructed a niche fitness evaluation model about the ecological niche of farmland quantity and the sustainable utilization of farmland.

Ecological theory holds that from the individual to the biosphere, both natural and social biological units have the properties of "ecostate" and "ecorole." Ecostate refers to state energy, biomass, number of individuals, resources, adaptability, and intelligence level of biological units, and is the result of past growth and development, as well as the accumulated interaction with the environment. Ecorole refers to the real influence or controlling power of biological units on the environment, such as exchange rates and growth rates between energy and substance, and the ability to occupy a new border. Ecological niche of a biological unit in a particular ecosystem reflects the relative position and role of the biological unit [16]. Well-facilitated capital farmland is a complete ecosystem that demands not only high and stable yield, but also a good ecological support for sustainable use of farmland. Therefore, when determining the ecological niche of well-facilitated capital farmland, we need to determine not only the state of the farmland, but also the influence or controlling power of the farmland on the environment.

Based on the niche ecostate-ecorole theory, conditions for constructing well-facilitated capital farmland are seen as a combination of "ecostate" and "ecorole" of the ecological niche. "Ecostate" means the current state of the farmland, that is, the basic situation of farmland resources mainly including land topography, soil texture, soil fertility, and infrastructure. "Ecorole" refers to the real and potential impact of the surroundings on farmland, such as the impact of construction and expansion of lands used for urban, industrial and traffic development, that is, the occupation probability of farmlands.

\section{Establishing the Evaluation Model}

In our paper we put forward an improved calculation formula for the ecological niche, based on the evaluation mode of classification and gradation for farmland by $\mathrm{Li}$ et al. [22]:

$$
\mathrm{N}=\mathrm{S} \times\left(1-F_{\mathrm{p}}\right) \times C
$$

...where $\mathrm{N}$ indicates the niche-fitness value; $\mathrm{S}$ the score of "ecostate", that is, the natural conditions of farmlands; $F_{p}$ the impact of neighboring units, such as urban land, industrial cluster area, roads etc., on evaluation units; $1-\mathrm{F}$ the probability that the farmland is not occupied; and $\mathrm{C}$ the decisive external conditions of the impact, with a value of 0 or 1 . If located in areas where land is allowed or is favorable to be used for construction and urban expansion, the farmland will be more likely to be occupied and used. Besides, since it is not suitable for constructing well-facilitated capital farmland in areas vulnerable to geological disasters, the value for the farmland in those areas is 0 , while the value for the farmland in other areas is 1 .
The suitability in well-facilitated capital farmland construction depends on the natural endowments of the farmland, such as soil texture, effective soil depth, soil organic matter content, slope, etc. These factors constitute an n-dimensional space of resources for wellfacilitated capital farmland. According to the restrictive law Shefold, deficiency in quantity or quality of any ecological factor will lead to the creature's recession or death [23]. Therefore, the calculation model for the ecostate value of niche fitness for well-facilitated capital farmland is expressed as follows:

The "ecostate" evaluation indicators for wellfacilitated capital farmland can be divided into 3 types. The first type is the positive factor. The bigger the factor value, the better the result. When the factor value exceeds a certain amount, its impact tends to be decreased. A case in point is organic matter content in soil. The evaluation model for this type of factor is:

$$
S_{k}= \begin{cases}0 & X_{k}<D_{k \min } \\ X_{k} / D_{k o p t} & D_{k \min } \leq X_{k}<D_{k o p t} \\ 1 & X_{k} \geq D_{k o p t}\end{cases}
$$

In the formula, $S_{k}$ stands for the niche fitness of each evaluation factor $k(k \in[1, n])$ of well-facilitated capital farmland; $X_{k}$ for the reality niche of evaluation factor $k ; D_{k o p t}$ for the optimal niche of evaluation factor $k$; and $D_{k \min }$ for the minimal niche of evaluation factor $k$.

The second type is suitability factor, the value of which exists in a suitable section. Whether its value is too large or too small, it will be a limiting factor of wellfacilitated capital farmland. $\mathrm{PH}$ value is a case in point. The evaluation model for this type of factor is:

$$
S_{k}= \begin{cases}0 & X_{k} \leq D_{k \min }, X_{k} \geq D_{k \max } \\ \left(X_{k}-D_{k \min }\right)\left(D_{k o p t}-D_{k \min }\right) & D_{k \min }<X_{k}<D_{k o p t} \\ \left(D_{k \max }-X_{k}\right)\left(D_{k \max }-D_{k o p t}\right) & D_{k o p t}<X_{k}<D_{k \max }\end{cases}
$$

...where $D_{k \max }$ stands for the maximum value of the niche of evaluation factor $k$.

The third type is the negative factor. That is to say, the smaller the factor value, the better the result. The soil contamination degree and so on belongs to this type. The evaluation model for this type of factor is:

$$
S_{k}= \begin{cases}1 & X_{k} \leq D_{k \min } \\ 1-\left(X_{k}-D_{k \min }\right)\left(D_{k \max }-D_{k \min }\right) & D_{k \min }<X_{k}<D_{k \max } \\ 0 & X_{k} \geq D_{k \max }\end{cases}
$$

The model of ecostate fitness of niche for wellfacilitated capital farmland is:

$$
\mathrm{S}=\left[\prod_{\mathrm{k}=1}^{m} S_{k}\right]^{1 / m}
$$


Table 1. Construction of "ecostate" evaluation index system for well-facilitated capital farmland in Xinzheng city.

\begin{tabular}{|c|c|c|c|}
\hline Evaluation index & $\begin{array}{l}\text { Most suitable } \\
\text { value }\end{array}$ & $\begin{array}{l}\text { Index } \\
\text { type }\end{array}$ & Source of index \\
\hline Soil texture & loam soil & Class 1 & $\begin{array}{l}\text { According to Regulation of Quality Classification of Agricultural Land (GB/T } \\
28405-2012) \text { and the content of sand, silt and clay in the land. We can divide } \\
\text { land into three types including Sandy soil, loam soil and Clay. Loam soil is the } \\
\text { best one among the three types. It can plant most crops, thus taking loam soil as } \\
\text { the most fitness. }\end{array}$ \\
\hline $\begin{array}{l}\text { Effective soil } \\
\text { thickness/cm }\end{array}$ & 100 & Class 1 & $\begin{array}{l}\text { The thicker the effective soil layer, the stronger the capacity of soil to hold wa- } \\
\text { ter, store water, remain fertile and supply fertile. According to Farmland Quality } \\
\text { Grade (GB/T33469-2016), as for the wheat and corn that Henan Province Plants, } \\
\text { when effective soil layer thickness reach } 100 \mathrm{~cm} \text {, it's the best thickness to let } \\
\text { plants grow. }\end{array}$ \\
\hline $\begin{array}{l}\text { Soil organic matter } \\
\text { content } /(\mathrm{g} / \mathrm{kg})\end{array}$ & 20 & Class 1 & $\begin{array}{l}\text { Soil organic matter is one of the most important indexes to measure the quality } \\
\text { of soil fertility. According to Farmland Quality Grade (GB/T 33469-2016) which } \\
\text { makes a classification of soil organic matter's content, we can know that } 20 \mathrm{~g} / \mathrm{kg} \\
\text { during each degree is the best optimum value. }\end{array}$ \\
\hline $\mathrm{pH}$ value & $6.0 \sim 7.9$ & Class 2 & $\begin{array}{l}\text { Different crops correspond to the appropriate range of appropriate } \mathrm{pH} \text {. Too } \\
\text { high and too low } \mathrm{pH} \text { is not conductive to the growth and development of crops. } \\
\text { According to Regulations of Quality Classification of Agricultural Land (GB/T } \\
\text { 28405-2012), it writes that when the pH of soil is between 6.0-7.9, it's the best } \\
\text { condition to let wheat and corn grow. }\end{array}$ \\
\hline $\begin{array}{l}\text { Soil contamination } \\
\text { grade } / \%\end{array}$ & 0 & Class 3 & Use pollution-free 0 as the most appropriate value as for soil pollution. \\
\hline Slope $/\left({ }^{\circ}\right)$ & 2 & Class 3 & $\begin{array}{l}\text { According to Regulations of Quality Classification of Agricultural Land (GB/T } \\
28405-2012) \text {, it says that the first degree during the slope steepness classifica- } \\
\text { tion, we can use the slope less than or equal to } 2^{\circ} \text { as the most appropriate value. }\end{array}$ \\
\hline $\begin{array}{c}\text { Drainage } \\
\text { condition/\% }\end{array}$ & 100 & Class 1 & $\begin{array}{l}\text { When water is accumulated in the field and lasts for a period of time, it will let } \\
\text { the root systems of the crops become hard to breath so that has an effect on the } \\
\text { grow and development of crops. In the construction of well-facilitated capital } \\
\text { farmland, drainage condition is the most important reconstructive and limited } \\
\text { factors, thus, drainage condition use the maximum value loo as the most appro- } \\
\text { priate value .In other words, any farmland could achieve unobstructed drainage } \\
\text { under this value. }\end{array}$ \\
\hline $\begin{array}{c}\text { Concentrated } \\
\text { degree } / \mathrm{hm}^{2}\end{array}$ & 333.33 & Class 1 & $\begin{array}{l}\text { According to appendix } \mathrm{C} \text { in the Assessment standard of well-facilitated con- } \\
\text { struction (GB/T } 33130-2016) \text {, when the contiguous scale of the high standards } \\
\text { are over } 333.33 \mathrm{hm}^{2} \text {, it's the most condition to do mechanized farming. }\end{array}$ \\
\hline $\begin{array}{c}\text { Country road } \\
\text { accessibility/m }\end{array}$ & 10 & Class 3 & $\begin{array}{l}\text { According to Assessment standard of well-facilitated construction } \\
\text { (GB/T 33130-2016), when the farmland is within } 10 \text { meters away from the field } \\
\text { road, it's convenient to facilitate the operation of agricultural equipment in and } \\
\text { out of the field. }\end{array}$ \\
\hline $\begin{array}{c}\text { Irrigation } \\
\text { guarantee rate } / \%\end{array}$ & 100 & Class 1 & $\begin{array}{l}\text { Due to uneven temporal and spatial distribution of rainfall, Xinzheng city is } \\
\text { located in semi-arid areas, agriculture has a dependence on irrigation, in the con- } \\
\text { struction of well-facilitated capital farmland, irrigation facilities are one of the } \\
\text { most important projects, thus, we use maximum value } 100 \text { as the most appropri- } \\
\text { ate. Under this condition, only crop could achieve adequate irrigation. }\end{array}$ \\
\hline
\end{tabular}

...where $S$ stands for the "ecostate" score and $m$ for the number of factors.

"Ecorole" $F_{p}$ mainly reflects the demand of economic development for land. The areas closer to cities, towns, and main roads are more likely to be occupied, and are less suitable for construction of well-facilitated capital farmland. Therefore, 2 indicators are used to show the ecorole impact of well-facilitated capital farmland, which include distances from cities, towns, and industrial cluster areas, and distances from main roads. The following formula can be used for valuation:
Table 2. Main influence factors and parameters of "ecorole" for well-facilitated capital farmland in Xinzheng city.

\begin{tabular}{|c|c|c|}
\hline Evaluation index & $\begin{array}{c}\text { Initial } \\
\text { score }\end{array}$ & Weight \\
\hline Distance from cities & 100 & 0.30 \\
\hline Distance from industrial cluster areas & 80 & 0.25 \\
\hline Distance from towns & 60 & 0.13 \\
\hline Distance from major roads & 100 & 0.32 \\
\hline
\end{tabular}




$$
\begin{aligned}
f_{i} & =\frac{M_{i}{ }^{1-r_{i}}}{100} \\
r_{i} & =d_{i} / d
\end{aligned}
$$

...where $f_{i}$ stands for index score, $M_{i}$ for scale index, $d_{i}$ for the actual distance of evaluation factors, $d$ for the impact radius of evaluation factors, and $r_{i}$ for relative distance.

Eventually, the assessment formula for well-facilitated capital farmland suitability is:

$$
\mathrm{N}=\left[\prod_{\mathrm{k}=1}^{m} S_{k}\right]^{1 / m} \times\left(1-\sum_{i=1}^{n} \omega_{i} f_{i}\right) \times \mathrm{C}
$$

... where $\omega_{i}$ stands for weights of influential neighboring units, such as lands used by cities and towns, industrial cluster areas, roads, etc.; $C$ stands for conditions of external influences; and $N$ is fitness index of wellfacilitated capital farmland construction.

\section{Results}

\section{Constructing the "Ecostate" and "Ecorole" Evaluation Index Systems of and Determining Parameters}

Since the well-facilitated capital farmland eco-system is very complicated, and the niche usually involves a wide resource space, a comprehensive analysis of all the "resources" is very difficult. As a result, according to the resource features of well-facilitated capital farmland, this research is focused on the analysis of resource factors that are essential for the construction of well-facilitated capital farmland. Based on the previous relevant research results [24], the index evaluation system is established in terms of "ecostate" and "ecorole" (Tables 1-2).

The "ecostate" of niche is the result of accumulated interaction between past land use and the environment [25]. In constructing the evaluation index system of "ecostate" for well-facilitated capital farmland, the factors of natural endowment and infrastructure should be taken into consideration, as shown in Table 1. The optimal niche should be determined on the basis of analyzing the present condition of land utilization, considering the types index. For instance, evaluation index $\mathrm{pH}$ value belongs to the middle type and there exists a most suitable section; index such as effective soil thickness belongs to the type of continuity, the bigger the better, and if surpassing a certain value, its effect will decrease. Determining the suitable value of such an index is based on Standards for Well-Facilitated Capital Farmland Construction (TD/T 1033- 2012), Standards for Well-Facilitated Farmland Construction (NY/T 2148-2012), Regulations of Quality Classification of Agricultural Land (GB/T 28405-2012), Assessment Standard of Well-Facilitated Farmland Construction (GB/T 33130-2016), and Farmland Quality Grade(GB/T 33469-2016). Soil texture and irrigation guarantee rate belong to the discrete type, and the bigger and better index is directly viewed as the most suitable value with a score of 100 points, as shown in Table 1.

"Ecorole" is the actual influence or power that surroundings impose on ecological units. Ecorole effects of well-facilitated capital farmland mainly come from the pressure of farmland occupation in industrialization and urbanization. The risk still exists even during or after the construction of well-facilitated capital farmland. According to the location theory, the expansion mode is divided into 2 kinds. One is the expansion of urban construction land. With rapid economic growth, farmland within cities and towns and in surrounding areas faces a considerable amount of pressure of being taken up. Therefore, among location factors, the distance from cities, towns, and industrial cluster areas is able to reflect the impact of location on farmland resource. The other is "leap" growth along major roads [26]. Since traffic lines play a strong guiding role towards farmland, which is of good transport accessibility and high convenience, it is more likely to turn into construction land. The main influence comes from roads within cities and towns, while highways, railways, and other transportation networks connecting other cities and towns exert little influence. Therefore, the distance from main roads is chosen as one of the indicators for evaluation. On the basis of consulting related literature and studying layout changes of farmland in recent years, the county's risk distance is $5 \mathrm{~km}$, industrial cluster areas' risk distance is $3 \mathrm{~km}$, township risk distance is $2 \mathrm{~km}$, and the major road risk distance is $0.5 \mathrm{~km}$. The impact of the well-facilitated capital farmland spacial stability will be getting smaller and smaller if risk distance exceeds this value. Set by experts, the initial score of main influence factors and weight of ecorole are shown in Table 2.

$C$ value mainly reflects the impacts of external conditions of well-facilitated capital farmland construction, which generally come from general land use planning and urban general planning in Xinzheng. For the extended areas of 2 industrial cluster areas in Xinzheng (the Integrated Experiment District of Aviation Economy of Zhengzhou and the Industrial Cluster Areas in New Air Harbor) and the extended regions determined by city planning, $C$ value of the farmland is 0 , and of other areas it is one.

\section{Analyzing the Evaluation Results}

According to the calculation in formulas (2)-(5), the "ecostate" value is distributed from 0 to 0.90 . The ecostate value of evaluation units is divided into 3 grades. Farmland of grade III with the score $(0,0.5)$ covers $1,646.28 \mathrm{hm}^{2}$, only $3.04 \%$ of the total area, comprising scattered pieces of land with less concentrated degree as the major obstacle that affects their scores; farmland of grade II with score $(0.5,0.75)$ covers $18,426.70 \mathrm{hm}^{2}$, $34.02 \%$ of the total area, which is mainly in the eastern part of Xinzheng; and farmland of grade I with score $(0.75,1)$ covers $34,094.95 \mathrm{hm}^{2}, 62.94 \%$ of the total area, with high concentration and good quality. From a general 


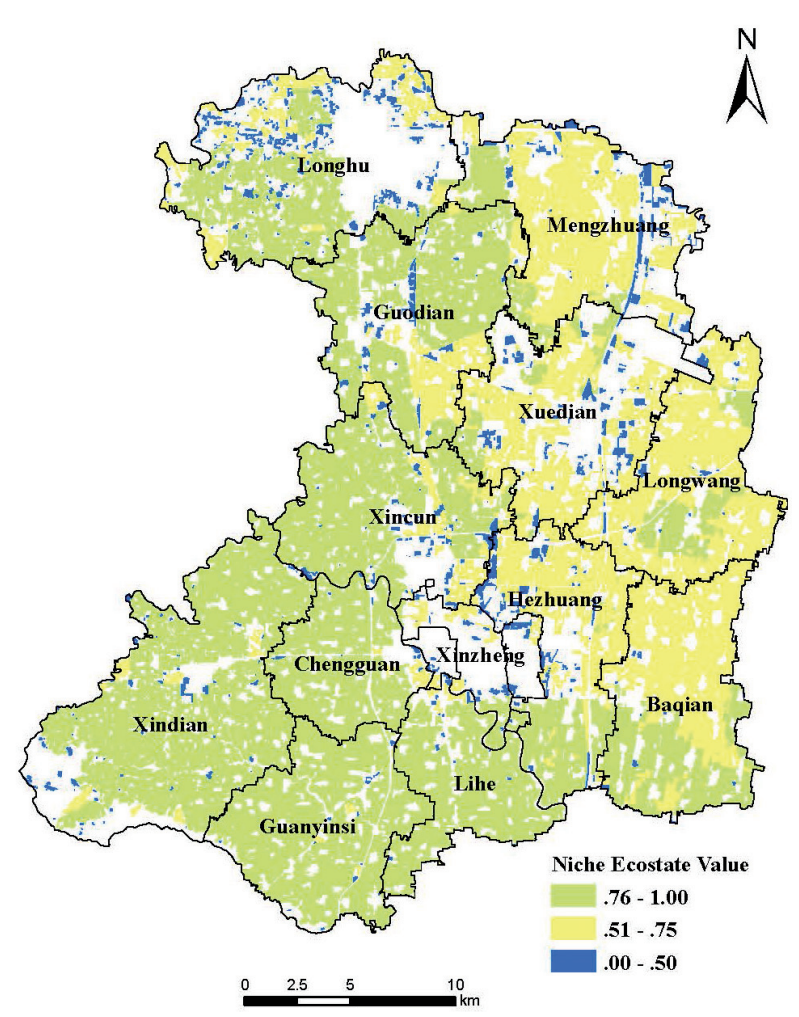

Fig. 2. The "ecostate" value map of well-facilitated capital farmland in Xinzheng.

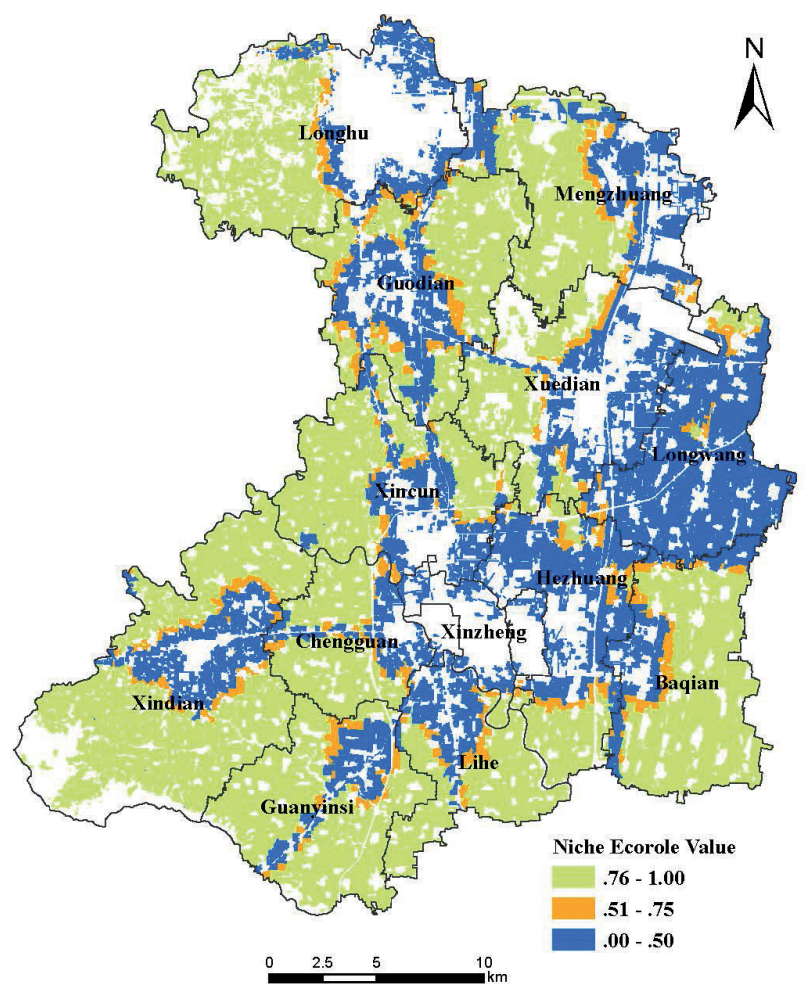

Fig. 3. The "ecorole" value map of well-facilitated capital farmland in Xinzheng. point of view, the farmland of grade I accounts for more than half of the total area of the farmland in Xinzheng, which shows that the farmland in Xinzheng is well endowed and has great potential to be constructed as well-facilitated capital farmland. The evaluation result is shown in Fig. 2.

The calculation results of niche ecorole for wellfacilitated capital farmland shows that farmland of grade I with score $(0.75,1)$ covers $32,918.11 \mathrm{hm}^{2}, 60.77 \%$ of the total area, which is mainly in the western, northern, and southern parts of Xinzheng; farmland of grade II with score $(0.5,0.75)$ covers $4,135.40 \mathrm{hm}^{2}, 7.63 \%$ of the total area, which is between grades I and III; and farmland of grade III with score $(0,0.5)$ covers $17,114.42 \mathrm{hm}^{2}$, or $31.6 \%$ of the total area. It is mainly distributed in Longwang, Xinzheng, and Mengzhuang, and the other parts are distributed around other towns, with poor space stability, which is extremely easy to be occupied. The evaluation result is shown in Fig. 3.

By using the software ArcGIS and Formula (8), the value of niche-fitness of all evaluation units can be calculated. Relevant studies [27-28] have shown that when the fitness index value $N=0.5$, it is at the bottom of suitable section of the evaluation factor, and therefore 0.5 is regarded as the threshold of fitness. That is to say, when fitness index value $N \leq 0.5$, this area is not suitable to be constructed, while when fitness index value $N>0.5$, the area is regarded as a suitable area. The suitable areas can be further divided into 3 types such as short- $(N>0.85)$, medium- $(0.75<\mathrm{n} \leq 0.85)$, and long-term $(0.5<\mathrm{n} \leq 0.75)$ construction areas. The area ratios of the 4 types of farmland to the total areas are, respectively, $18.17 \%$, $24.65 \%, 20.36 \%$, and $36.82 \%$. The combined area of farmland for short- and medium-term construction covers $42.82 \%$ of the total area. This type of area has generally high-quality farmland with high concentrated degree, mainly located in the southwest and northern parts of Xinzheng. Farmland in the long-term construction areas is obviously scattered and distributed among other types of areas. The areas unsuitable for construction are mainly distributed in the city center, industrial cluster areas, and surroundings of important towns. The farmland of this type is more likely to be occupied as shown in Table 3 and Fig. 4.

\section{Discussions}

\section{To Construct Well-Facilitated Capital Farmland and Ensure Food Security}

Farmland is one of the most basic means of agricultural production, and any crop with high quality and yield must be based on farmland of good amount and quality [29]. However, the amount of the farmland per capita in China is now small, and the farmland with high quality is also limited. There is not much reserve farmland, with poor infrastructure and low concentrated degree [30-33]. There is a big gap between the present condition for most 
Table 3. Space layout table for well-facilitated capital farmland in Xinzheng city.

\begin{tabular}{|c|c|c|c|c|c|}
\hline $\begin{array}{l}\text { Construction } \\
\text { sequence }\end{array}$ & $\begin{array}{l}\text { Farmland } \\
\text { area/hm }\end{array}$ & $\begin{array}{l}\text { The ratios of the } \\
\text { total farmland } \\
\text { areas }\end{array}$ & $\begin{array}{l}\text { The } \\
\text { number } \\
\text { of plots }\end{array}$ & $\begin{array}{l}\text { The ratio } \\
\text { of plot }\end{array}$ & The distribution area \\
\hline $\begin{array}{c}\text { Short-term } \\
\text { construction areas }\end{array}$ & $9,840.15$ & $18.17 \%$ & 2694 & $13.18 \%$ & $\begin{array}{l}\text { This kind of farmland are mostly distributed in } \\
\text { the plains of the southwestern part of Xinzheng, } \\
\text { represented by several towns such as Xindian } \\
\text { Guanyinsi, Chengguan, and Lihe. }\end{array}$ \\
\hline $\begin{array}{c}\text { Medium-term } \\
\text { construction areas }\end{array}$ & $13,355.02$ & $24.65 \%$ & 5245 & $25.67 \%$ & $\begin{array}{l}\text { This kind of farmland are mainly distributed in the } \\
\text { northwest, central and southeast parts of Xinzheng, } \\
\text { represented by several towns such as Xincun, } \\
\text { Xindian, the southern part of Baqian, the western } \\
\text { part of Longhu, Guodian and Lihe. }\end{array}$ \\
\hline $\begin{array}{c}\text { Long-term } \\
\text { construction areas }\end{array}$ & $11,029.32$ & $20.36 \%$ & 4209 & $20.60 \%$ & $\begin{array}{l}\text { In terms of spatial distribution, most of the farm- } \\
\text { land of this type is located in hilly areas, with a } \\
\text { small part distributed in plains, represented by } \\
\text { several towns such as Mengzhuang, Guodian and } \\
\text { Xuedian. }\end{array}$ \\
\hline $\begin{array}{c}\text { Unsuitable } \\
\text { construction areas }\end{array}$ & $19,943.45$ & $36.82 \%$ & 8286 & $40.55 \%$ & $\begin{array}{l}\text { This type of farmland is mainly distributed in the } \\
\text { city center, nearby the town centers and in the hill, } \\
\text { which is represented by towns such as Longwang, } \\
\text { Baqian and Mengzhuang. }\end{array}$ \\
\hline
\end{tabular}

Note: The construction of the high-quality capital farmland aims at the comprehensive renovation of farmland, water, road, woods, and villages, and therefore field ridges, irrigation canals, and country roads are also included in this study's statistics besides the cultivated area.

of the farmland and requirements of high stable yield and modernized agricultural production. Today and in the near future, China is experiencing rapid economic

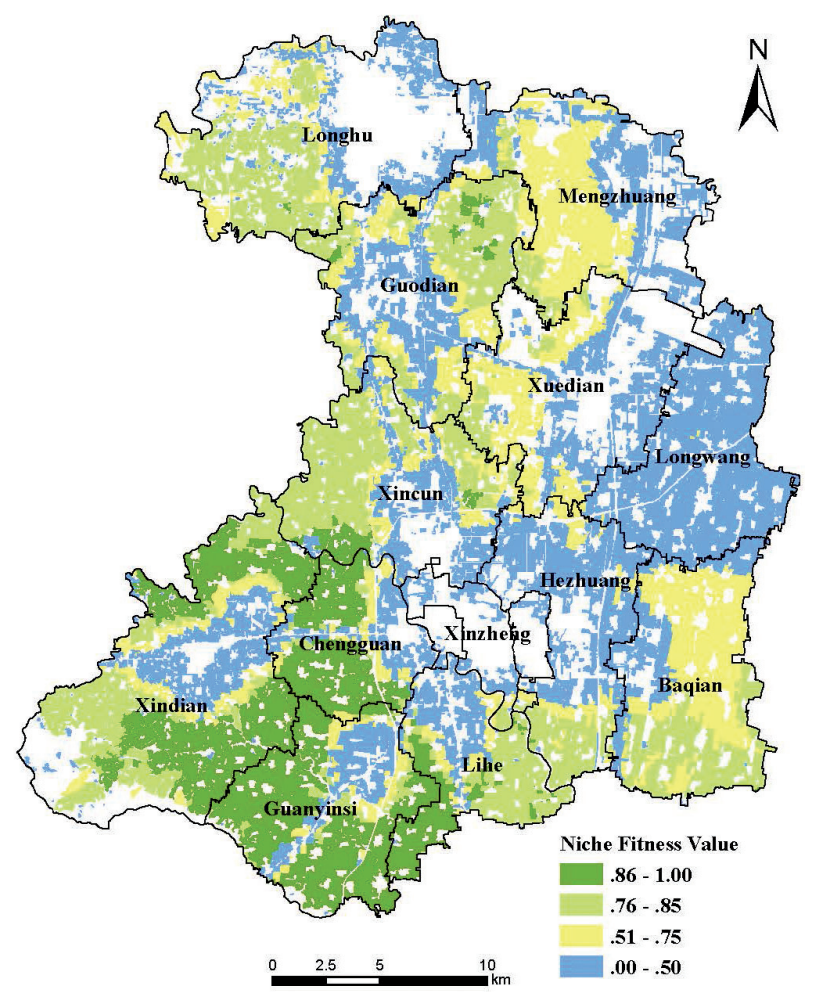

Fig. 4. The niche-fitness value map of well-facilitated capital farmland in Xinzheng. development, and the demand of construction land will further increase. And a large amount of high-quality farmland will be taken up, which will undoubtedly severely threaten China's food security. Therefore, the Chinese government will begin to vigorously reorganize and manage rural land and construct wellfacilitated capital farmland on a large scale, in the hope of effectively solving problems such as low concentrated degree, inadequate facilities, deterioration of farmland environment, etc. To enhance agricultural anti-disaster ability and improve integrated food production capacity we can upgrade guaranteed capacity for food security and speed up agricultural modernization with Chinese characteristics which stresses the change of agricultural development mode, and also bring people benefits in increasing income and constructing comfortable homeland.

\section{Evaluation Methods of Well-Facilitated Capital Farmland Construction}

Now the well-facilitated capital farmland construction is a new research topic, and has been carried out throughout the country. However, there are some problems in the process of construction, such as the inconsistency between capital input and natural endowment of land resources, scattered investment, and difficulties in bringing comprehensive benefits [1]. The root cause of these problems lies in the failure of taking local conditions into consideration in terms of site selection and planning of well-facilitated capital farmland construction. Therefore, to carry out systematic 


\begin{tabular}{|c|c|c|c|c|c|c|c|c|c|c|c|c|c|c|c|}
\hline & 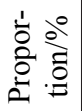 & 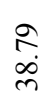 & $\begin{array}{l}\infty \\
\stackrel{y}{y} \\
\stackrel{y}{y}\end{array}$ & $\begin{array}{l}\text { fे } \\
\text { dें }\end{array}$ & $\begin{array}{l}\text { స̂. } \\
\text { in }\end{array}$ & $\begin{array}{l}8 \\
\stackrel{2}{2}\end{array}$ & 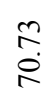 & $\begin{array}{l}\hat{\alpha} \\
\infty \\
\infty\end{array}$ & $\stackrel{\stackrel{\Omega}{\infty}}{\stackrel{\infty}{=}}$ & $\begin{array}{c}f \\
\dot{d} \\
i d\end{array}$ & ते & $\begin{array}{l}\infty \\
\stackrel{+}{d}\end{array}$ & $\begin{array}{l}\stackrel{f}{\infty} \\
\infty \\
\infty\end{array}$ & $\stackrel{尺}{\stackrel{8}{\infty}}$ & $\begin{array}{l}n \\
\tilde{c} \\
\dot{c}\end{array}$ \\
\hline & $\frac{\overrightarrow{0}}{2}$ & \& & 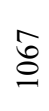 & $\frac{n}{6}$ & $\tilde{\infty}$ & $\vec{D}$ & $\stackrel{\Xi}{\Xi}$ & $\hat{\sigma}$ & ఏ & $\widetilde{\widetilde{\imath}}$ & $\stackrel{\infty}{\infty}$ & $\frac{\Delta}{m}$ & $\frac{0}{m}$ & तิ & $\begin{array}{l}\infty \\
\infty \\
\infty \\
\infty\end{array}$ \\
\hline & 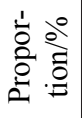 & $\frac{\stackrel{8}{0}}{\dot{m}}$ & $\begin{array}{l}\tilde{n} \\
\stackrel{n}{n}\end{array}$ & $\begin{array}{l}\underset{f}{\text { i }} \\
\text { ల్ల }\end{array}$ & $\stackrel{\Re}{\stackrel{g}{q}}$ & $\begin{array}{l}\delta \\
\stackrel{\delta}{\sim}\end{array}$ & $\begin{array}{l}8 \\
\dot{6}\end{array}$ & $\begin{array}{l}\hat{N} \\
\infty \\
-\infty\end{array}$ & 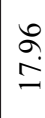 & 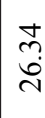 & $\underset{i}{\stackrel{\sim}{i}}$ & $\stackrel{\infty}{\stackrel{\infty}{\lambda}}$ & $\frac{a}{a}$ & $\begin{array}{l}\overrightarrow{+} \\
\dot{\infty}\end{array}$ & $\begin{array}{l}\tilde{\alpha} \\
\dot{\infty} \\
\tilde{D}\end{array}$ \\
\hline & 异 & 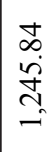 & $\begin{array}{l}\text { त̂ } \\
\text { \&. } \\
\infty \\
\stackrel{0}{-}\end{array}$ & 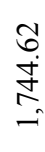 & 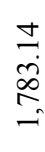 & 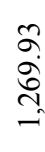 & $\begin{array}{l}\text { ते } \\
\text { ते } \\
\text { î }\end{array}$ & $\begin{array}{l}n \\
0 \\
0 \\
0 \\
\sim \\
-1\end{array}$ & $\overrightarrow{5}$ & $\begin{array}{l}= \\
2 \\
2\end{array}$ & $\begin{array}{l}\sqrt{n} \\
\stackrel{\hat{\sigma}}{\sigma}\end{array}$ & 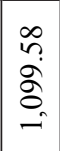 & 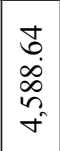 & 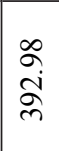 & $\begin{array}{l}o \\
+ \\
\dot{j} \\
\dot{\alpha} \\
2\end{array}$ \\
\hline & 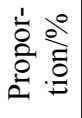 & $\stackrel{5}{a}$ & $\frac{\infty}{\dot{q}}$ & $\stackrel{\stackrel{\sim}{\sim}}{\stackrel{\sim}{N}}$ & 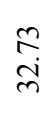 & $\overrightarrow{\mathrm{d}}$ & $\begin{array}{l}\text { J } \\
\text { త }\end{array}$ & $\underset{\infty}{\infty}$ & $\begin{array}{l}7 \\
\infty \\
\infty\end{array}$ & $\stackrel{\widehat{N}}{=}$ & $\stackrel{n}{=}$ & $\stackrel{\stackrel{n}{f}}{\dot{\nabla}}$ & $\stackrel{?}{\stackrel{S}{-}}$ & 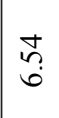 & $\begin{array}{l}\stackrel{8}{0} \\
\stackrel{i}{1}\end{array}$ \\
\hline & $\frac{\overrightarrow{0}}{2}$ & ర్ర & స్ & $\stackrel{\overbrace{}}{\digamma}$ & $\underset{i n}{ \pm}$ & $\stackrel{+}{n}$ & $\underset{\sim}{\stackrel{\sim}{~}}$ & లి & a & $\alpha$ & $\infty$ & $\vec{\sim}$ & $\stackrel{2}{2}$ & $\beth$ & $\begin{array}{l}\stackrel{\mathrm{N}}{\text { f }} \\
\text { f }\end{array}$ \\
\hline & 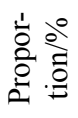 & $\begin{array}{l}\stackrel{9}{q} \\
\infty \\
\infty\end{array}$ & $\stackrel{?}{\dot{m}}$ & $\vec{\sim}$ & 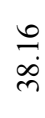 & 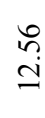 & $\stackrel{g}{g}$ & $\bar{n}$ & $\stackrel{0}{\stackrel{0}{r}}$ & $\begin{array}{l}: \\
\infty \\
\infty\end{array}$ & $\stackrel{n}{=}$ & $\underset{i}{\vec{f}}$ & $\frac{\pi}{0}$ & $\stackrel{\sim}{\sim}$ & 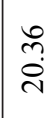 \\
\hline & 娄 & 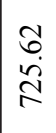 & 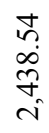 & $\begin{array}{l}\hat{\sigma} \\
\stackrel{\sim}{N}\end{array}$ & $\begin{array}{l}\stackrel{m}{0} \\
0 \\
\stackrel{0}{0} \\
\stackrel{0}{-}\end{array}$ & $\begin{array}{l}\frac{1}{8} \\
\stackrel{8}{\circ}\end{array}$ & $\frac{\stackrel{+}{I}}{\stackrel{F}{f}}$ & $\stackrel{\vec{\jmath}}{\stackrel{n}{r}}$ & $\begin{array}{l}\tilde{D} \\
\infty \\
\dot{b} \\
m\end{array}$ & $\begin{array}{l}n \\
\tilde{d} \\
\text { di }\end{array}$ & $\begin{array}{l}\tilde{m} \\
\hat{d} \\
\tilde{m}\end{array}$ & 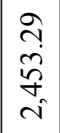 & \begin{tabular}{l}
\multirow{J}{*}{} \\
$\stackrel{j}{*}$
\end{tabular} & $\begin{array}{l}0 \\
\infty \\
\varrho \\
\varrho\end{array}$ & $\begin{array}{l}\text { aे } \\
\text { రิ } \\
=\end{array}$ \\
\hline & $\begin{array}{l}0 \\
0 \\
0 \\
0\end{array}$ & $\begin{array}{l}\stackrel{\infty}{\infty} \\
\vec{\forall}\end{array}$ & $\underset{\infty}{\tilde{\infty}}$ & \begin{tabular}{l} 
त̃ \\
\multirow{J}{*}{}
\end{tabular} & $\stackrel{8}{\stackrel{8}{=}}$ & 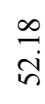 & $\frac{1}{0 .}$ & $\frac{\infty}{\stackrel{m}{m}}$ & 8 & $\begin{array}{l}\stackrel{8}{ } \\
\stackrel{j}{d}\end{array}$ & î & $\begin{array}{l}\sigma \\
\dot{m} \\
\dot{m}\end{array}$ & $\stackrel{n}{0}$ & 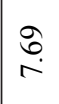 & $\begin{array}{l}\hat{\sigma} \\
\dot{j}\end{array}$ \\
\hline & $\frac{\vec{o}}{Q}$ & $\stackrel{\vec{\sigma}}{\stackrel{\sigma}{0}}$ & $\underset{\sim}{\stackrel{\sim}{2}}$ & $\widetilde{\infty}$ & 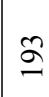 & $\underset{\Xi}{\stackrel{2}{O}}$ & $\hat{n}$ & $\underset{\infty}{\infty}$ & $\hat{\sigma}$ & $\underset{\sim}{\stackrel{0}{0}}$ & $\stackrel{\infty}{\infty}$ & $\stackrel{n}{\gamma}$ & $\sim$ & $\stackrel{\sim}{\text { N }}$ & 㨍 \\
\hline & 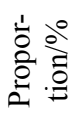 & $\overrightarrow{\stackrel{ }{\sigma}}$ & å & $\begin{array}{l}\text { రీ} \\
\stackrel{m}{\circ}\end{array}$ & $\vec{\Xi}$ & $\begin{array}{l}8 \\
\tilde{n} \\
\hat{n}\end{array}$ & 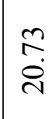 & $\begin{array}{l}\hat{a} \\
\hat{\sim}\end{array}$ & $\begin{array}{l}0 \\
0 \\
i\end{array}$ & $\begin{array}{l}q \\
\dot{m} \\
\text { m. }\end{array}$ & $\stackrel{8}{+}$ & $\begin{array}{l}\vec{\infty} \\
\dot{\infty}\end{array}$ & : & $\stackrel{+}{n}$ & $\begin{array}{l}n \\
\dot{j} \\
\dot{j}\end{array}$ \\
\hline & 娄 & 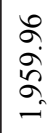 & $\frac{7}{\overrightarrow{7}}$ & 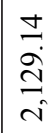 & $\begin{array}{l}n \\
\dot{+} \\
\dot{f}\end{array}$ & $\mid \begin{array}{c}\infty \\
\infty \\
\infty \\
\\
i \\
i\end{array}$ & $\begin{array}{l}\text { जे } \\
\stackrel{+}{N}\end{array}$ & $\begin{array}{l}\stackrel{n}{\hat{~}} \\
\stackrel{\tilde{\sigma}}{0} \\
i\end{array}$ & 恿 & $\begin{array}{l}0 \\
0 \\
\hat{\tilde{D}} \\
-1\end{array}$ & 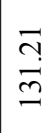 & $\begin{array}{l}\infty \\
\stackrel{\infty}{+} \\
\stackrel{+}{\infty} \\
\stackrel{2}{\sim}\end{array}$ & $\stackrel{\partial}{\dot{m}}$ & $\begin{array}{l}\infty \\
\infty \\
n \\
n\end{array}$ & $\begin{array}{l}\tilde{\delta} \\
\dot{n} \\
n \\
\tilde{n} \\
\tilde{n}\end{array}$ \\
\hline & 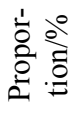 & ते & $\stackrel{8}{\circ}$ & $\stackrel{\bullet}{\stackrel{f}{f}}$ & $\stackrel{8}{\circ}$ & $\stackrel{n}{0}$ & $\frac{9}{0}$ & त̂ & $\stackrel{\overbrace{}}{\stackrel{5}{6}}$ & 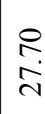 & $\begin{array}{l}\text { to } \\
\text { in }\end{array}$ & ?ֶ. & $\stackrel{8}{0}$ & $\stackrel{8}{0}$ & $\stackrel{\infty}{\stackrel{\infty}{g}}$ \\
\hline & $\frac{\vec{o}}{2}$ & $r$ & 0 & $\Phi$ & 0 & $\bar{\beth}$ & $m$ & $\tilde{\varrho}$ & in & $\underset{\sim}{\sim}$ & 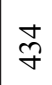 & $r$ & 0 & 0 & 志 \\
\hline & $\begin{array}{l}\frac{1}{0} \\
\frac{0}{2}\end{array}$ & خे & $\stackrel{8}{\circ}$ & $\vec{\sim}$ & $\stackrel{8}{\circ}$ & $\begin{array}{l}\sigma \\
0 \\
0 \\
0\end{array}$ & $\stackrel{\infty}{0}$ & $\frac{n}{5}$ & $\begin{array}{l}\dot{a} \\
\dot{0} \\
\dot{0}\end{array}$ & $\begin{array}{l}: \\
\stackrel{\leftrightarrow}{े} \\
\text { in }\end{array}$ & $\begin{array}{l}\infty \\
\stackrel{\infty}{6}\end{array}$ & $\stackrel{0}{\stackrel{1}{0}}$ & $\stackrel{8}{0}$ & 8 & $\stackrel{-1}{\infty}$ \\
\hline & 娄塄 & $\stackrel{n}{=}$ & 0 & $\begin{array}{l}\text { ô } \\
\stackrel{\leftrightarrow}{0} \\
\text { d }\end{array}$ & 0 & तై & $\vec{f}$ & 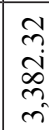 & $\begin{array}{l}m \\
\hat{j} \\
\stackrel{d}{j} \\
m\end{array}$ & $\frac{n}{\alpha}$ & 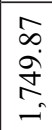 & $\hat{a}$ & 0 & 0 & \begin{tabular}{l}
$n$ \\
$\stackrel{+}{+}$ \\
\multirow{\infty}{\infty}{}
\end{tabular} \\
\hline \multicolumn{2}{|c|}{ 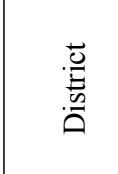 } & 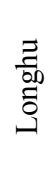 & 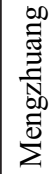 & 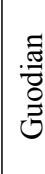 & 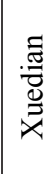 & 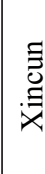 & 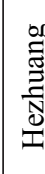 & 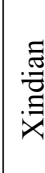 & 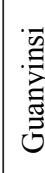 & $\stackrel{8}{5}$ & 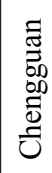 & 恚 & 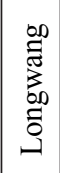 & 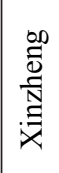 & 要 \\
\hline
\end{tabular}


studies on evaluation method of well-facilitated capital farmland construction, this has become a very important topic. Chinese scholars have built a series of evaluation models, such as an ideal approximation method [5], principal component analysis [24], 4-quadrant method [6], LESA method [34], and others. But these methods are almost the same as traditional land evaluation methods, which seldom analyze the problem from an overall regional perspective, considering only natural and economic conditions and ignoring the impact of government orientation and related policy restrictions on farmland. Nevertheless, the regional assignment for construction of well-facilitated capital farmland is a quite complicated job, which not only requires technology and the need to take into consideration social economic conditions, but also government orientation and related policy restrictions. This is why our paper introduces the ecostate and ecorole models into the research of the well-facilitated capital farmland construction. The ecostate value reflects the quality of farmland while ecorole reflects the social economic development and spatial stability, and the $C$ value reflects the restrictions of national and local policies. For example, the main areas of urban development in land use planning and urban planning in recent years, the farmland in these areas may become construction land in coming years. If well-facilitated capital farmland is built in these areas, the farmland that was occupied will cause great waste. Thus, this article introduces $\mathrm{C}$ value, which in this region is assigned " 0 ." The model overcomes the limitation in well-facilitated capital farmland construction, in which niche fitness has been neglected and improves realistic feasibility.

\section{Analysis of Classification of Well-Facilitated Capital Farmland}

Apart from the basic production function, wellfacilitated capital farmland construction also has some social functions such as ecological service and social security. According to the different values of niche fitness index, in the study areas for farmland construction are divided into 4 types (Fig.4), and acreage and other related land data in different towns are calculated (Table 4).

1) The short-term construction area is actually the optimal construction area. The natural conditions, and utilization conditions, and concentrated degree and the ecological security of the farmland are best, almost without any obstacle. Engineering construction is rather easy, with small inputs but big returns. There is much space to be improved for land quality and landscape ecological conditions, and once the construction is completed, the productivity of the farmland will continually be improved. It is the core area of capital farmland protection, and the preferred area for well-facilitated capital farmland construction. This kind of farmland covers $9,840.15 \mathrm{hm}^{2}, 18.17 \%$ of the total area of farmland in the city. The number of plots of such farmland is 2,694, or $13.18 \%$ of the total number of those in the whole city.
It can be seen from the ratio of the acreage of farmland to the number of the plots that the plots of this type of farmland are generally large and highly concentrated. This kind of farmland is mostly distributed in the plains of the southwestern part of Xinzheng, represented by several towns such as Xindian Guanyinsi, Chengguan, and Lihe, and a little of the farmland is located in hilly areas (Table 4). Farmland in this type of area has good natural endowment and complete infrastructure, with a highly concentrated degree and supported by the people. Therefore, it is quite suitable for the development of modern agriculture. In the construction process, the overall arrangement for land utilization and agricultural production should be improved through scientific merging of field plots and reasonable layout of rural residences; irrigation facilities should be maintained and upgraded, and the more economical and efficient sprinkling and dropping methods of irrigation are encouraged to be adopted to improve water utility efficiency. The focus should be put on the arrangement of drainage facilities, field roads and the farmland shelterbelt system, with the aim at improving supporting capacity of farmland infrastructure toward agricultural production, and great efforts should be made to explore agricultural production modes with characteristics, promote large-scale farmland management, improve the overall economic benefits of agricultural land, and lay the foundation for the development of high-yielding modernized agriculture.

2) Medium-term construction area, which is also considered a suitable construction area. Although infrastructure and farmland quality cannot be compared with the short-term construction area, there is no obvious obstacle. The land in the area needs to be rearranged and managed and to achieve that is also feasible. Therefore, this type of area may also be considered to be constructed as well-facilitated capital farmland. This type of farmland covers $13,355.02 \mathrm{hm}^{2}, 24.65 \%$ of the city's total farmland area, which is mainly distributed in the northwest, central and southeast parts of Xinzheng, represented by several towns such as Xincun, Xindian, the southern part of Baqian, and the western part of Longhu, Guodian, and Lihe. The number of plots of such farmland is 5,245, or $25.67 \%$ of the total number of those in the whole city. Compared with the short-term area construction, the land plots for the medium-term construction are relatively fragmented and easily occupied by other building programs, and usually with irregular shapes. As a result, the overall fitness degree of the farmland is relatively low, which brings about restrictions to the size effect of agricultural modernization. In future construction, efforts should be made to change the traditional distribution mode centered on household land, and increase the concentrated degree of the farmland by land levelling, road projects in the field, and property right adjustment, with the aim of realizing the transformation from the suitable construction area to the optimal construction area.

3) Long-term construction area. There are some apparent obstacles in this type of farmland in terms 
of natural conditions, spatial patterns, and ecological security. Therefore, the various obstacles should be carefully inspected and then different land rearranging modes are adopted to improve farmland quality. And the well-facilitated capital farmland may be moderately constructed in this type of area. This type of farmland covers $11,029.32 \mathrm{hm}^{2}$, or $20.36 \%$ of the city's total farmland area. The number of plots of such farmland is 4,209 , or $20.60 \%$ of the total number of those in the whole city (Table 4). In terms of spatial distribution, most of the farmland of this type is located in hilly areas, with a small part distributed in plains. This type of farmland is usually distributed in the midst of other types of farmland, and the shapes of the land plots are largely irregular (Fig. 4). This type of land is mainly located in towns such as Mengzhuang, Guodian, and Xuedian. Therefore, a land improvement project of this type of land should be focused on such points as to provide irrigation and drainage facilities, to dredge waterways, to improve irrigation infrastructure and agricultural production conditions, and increase the concentrated degree of farmland, with the aim of realizing the transformation of agricultural growth patterns from extensive to intensive.

4) The area in which construction is not suitable for the present. Due to the increasingly strengthened obstacles of natural quality, farming conditions, ecological safety, and spatial stability, the comprehensive fitness degree of the farmland is very low, and therefore this type of area is not suitable to be selected for well-facilitated capital farmland construction. This kind of farmland covers $19,943.46 \mathrm{hm}^{2}$, or $36.82 \%$ of the city's total farmland area. The number of plots of such farmland is 8,286 , or $40.55 \%$ of the total number of those in the whole city (Table 4). This type of farmland is mainly distributed in the city center or nearby the town centers and in the hill, which is represented by towns such as Longwang, Baqian, and Mengzhuang (Fig. 4). The main reason is that this type of area is the key area for the future development of Xinzheng, and the farmland in the area is faced with a greater threat of urbanization and industrial development pressures, which will most likely be deserted or used for other purposes because of the low farmland benefits. Since the farmland is easily occupied and the spatial stability is very poor, it is not suitable for well-facilitated capital farmland construction. Considering the fast urban development and the high probability of being occupied, farmland in this type of area may be used for city parks and public greenbelts, which function as the "green lung" of city development with surrounding farmland to prevent the endless expansion of urban space.

\section{Conclusions}

In the study the niche ecostate-ecorole theory is applied into the study of well-facilitated capital farmland construction, in which the fitness degree of the wellfacilitated capital farmland construction in Xinzheng, Henan province in China is evaluated in detail, with findings consistent with the city's reality. With clear ecological meaning, the study enriches the evaluation theory and method of well-facilitated capital farmland construction, and lays a foundation for the study of well-facilitated capital farmland construction in the perspective of ecological niche.

In our study the ecological niche mode is used to study the fitness degree of well-facilitated capital farmland construction. Generally speaking, the natural condition is relatively good, and the farmland in the whole city is suitable for well-facilitated capital farmland construction covering $34,224.48 \mathrm{hm}^{2}$, or $63.18 \%$ of the total farmland area, which is mainly distributed in the southern and northwestern parts of Xinzheng. Of the farmland, the short-term construction area covers $9,840.15 \mathrm{hm}^{2}$, or $18.17 \%$ of the total area; the medium-term construction area is $13,355.02 \mathrm{hm}^{2}$, or $24.65 \%$ of the total area; the long-term construction area is $11,029.32 \mathrm{hm}^{2}$, or $20.36 \%$ of the total area; the area unsuitable for construction is $19,943.45 \mathrm{hm}^{2}$, or $36.82 \%$ of the total area.

\section{Acknowledgements}

Sincere thanks are due to the anonymous reviewers for their helpful comments. This research was funded by the National Natural Science Foundation of China (Nos. 41641057 and 41371524).

\section{Conflict of Interest}

The authors declare no conflict of interest.

\section{References}

1. LI S.S., YUN W.J. Issues and approaches to the construction of high-standard of basic farmland. Resour Ind. 14 (3), 189, 2012.

2. LIU X.W., LI J.Y., ZHAO C.L. On building 4 hundred million of high-standard basic farmland in the twelfth five-year plan. China Popul, Resour Environ. 22 (3), 1, 2012.

3. WANG C., WANG J.K., LT H.D., LI S.Y. Research on regional distribution and potentiality of high-standard basic farmland. China Population, Resour Environ. 24 (5), 226, 2014.

4. CUI Y., LIU Z.W. A GIS-based approach for suitability evaluation of high standard primary farmland consolidation: A case from Huairou in Beijing. China Land Sci. 28 (9),76, 2014.

5. FENG R., WU K.N., WANG Q. Time sequence and mode partition of high-standard prime farmland construction in Zhongjiang county, Sichuan province. Trans. Chine Soc. Agric. Eng. (Trans. CSAE). 28 (22), 243, 2012.

6. TANG X.M., PAN Y.C., LIU Y., REN Y.M. Layout and mode partition of high-standard basic farmland construction at county level based on four-quadrant method. Trans. Chine Soc. Agric. Eng. (Trans. CSAE). 30 (13), 238, 2014 
7. ZHOU S.Y., ZHU A.X., QIU W.L, LIU F., DAI J.C. GIS based connectivity analysis and its application in prime farmland protection planning. Trans. Chine Soc. Agric. Eng. (Trans. CSAE). 24 (7), 72, 2008.

8. PAN H.Y., JING W.L., FAN T., MA H.J. The sequence of farmland comprehensive consolidation under the guidance of plan and the constraint of cultivated land quality. China Land Sci. 29 (8), 81, 2015.

9. GRINNELl, J. Geography and evolution. Ecology. 5, 225, 1924.

10. EITON C.S. Animal Ecology. London: Sidgwick and Jackson. 63, 1927

11. HUTCHINSON G.E. Concluding remarks. Cold Spring Harbor Symp Quant. Biol. 22, 415, 1957.

12. WHITTAKER R.H., LERIN S.A., BOOT R.B. Niche, Habitat and Ecotope. Amer Nat. 107 (955), 321, 1973.

13. ODUM R.P. Basic Ecology. CBS College Publishing, 1983.

14. LRIBOLD M.A. The nice concept revisited: mechanistic models and community context. Ecology. 76 (5), 1371, 1995.

15. LI Z.Z., ZHAO S.L., ZHANG P.Y. The niche-fitness theory and its application to the systems of crop growth. J Lanzhou U (Nat sci). 29 (4), 219, 1993.

16. ZHU C.Q. The niche ecostate-ecorole theory and expansion hypothesis. Acta ecol sin. 17 (3), 324, 1997.

17. ZHANG X., GE X.D., PU L.J., HUANG X.J., PENG B.Z. A study on the economic niche of land use theory and mechanisms of cropland conservation. J nat resour. 06, 677, 2002.

18. WANG R.Y., ZHAO G.X., YU Z.W., ZHANG Y.T., ZHANG H.Y. Assessment of land use effects on environmental vulnerability by ecological niche suitability model. Trans. Chine Soc. Agric. Eng. (Trans. CSAE). 28 (11), 218, 2012.

19. WANG H.H., LIU Y.F. Research on optimal allocation model of land resource based on niche and CA: the Case of Huangpi. China Population, Resour Environ. 18 (2), 97, 2008.

20. LI H.B., ZHANG H., ZHAO J.S., YUAN L. Evaluation on land suitability for development and construction in low hill and gentle slope area based on CA-Niche-Suitability Model. China Land Sci. 28 (6), 23, 2014.

21. NIU H.P., ZHAO T.Q., ZHANG A.L. Cultivated land sustainable use evaluation based on niche-fitness. Acta Ecol Sintca. 29 (10), $5535,2009$.

22. LI L.F., LI M.G. Improving the quality of farmland and ensuring food security in China. Mod Manage. 05, 4, 2013.
23. MENG L.N., ZHENG X.Q., ZHAO L., DDEN J. Land-use functional regionalization based on niche-fitness model. Trans. Chine Soc. Agric. Eng. (Trans. CSAE). 27 (3), 282, 2011.

24. TAN X., WANG X.R., TANG HZ. Evaluation index system and method on construction condition of county well-facilitied capital farmland: A case study of Mianzhu country. Southwest China J Agric Sci. 26 (5), 1977, 2013.

25. CHEN Y., ZHANG R.Z., CHEN B., ZHANG J., CHEN N.L. Construction and application on the niche theory of land-use. Arid Land Geog. 33 (5) ,791,2010.

26. XUE J. Study on the Criteria and Construction Approach for Well-facilitated Farmland: A Case Study in Fujin City, Heilongjiang Province. China Agr Univ, 2014 [In China].

27. MUKTHAR ELAALEM, ALEXIS COMBER, PETER FISHEER. A comparison of fuzzy AHP and ideal point methods for evaluating land suitability. Trans GIS, 15 (3), 329, 2011.

28. DDENG F., LI X.B., WANG H., XU L. GIS-based assessment of land suitability for alfalfa cultivation: A case study in the dry continental steppes of northern China. Spa J Agric Res. 12 (2), 364, 2014.

29. LI Z., ZHOU S.L., WU S.H., WU L.G., WU Y.Y. The improvement of the urban fringe rural settlements land towards urbanization based on niche fitness evaluation. Sci geogr sin. 08, 972, 2013.

30. LU Y.Y. Discussion on the five models of high standard farmland in China. Resour Guide. 02, 22, 2016.

31. 31. ZHANG Y.Q., WANG L.Y., LI M.C., LI F.X., ZHU A.X., CHEN D. Delineation of a permanent basic farmland protection area around a city centre: Case study of Changzhou City, China. Land use policy. 60, 73, 2017.

32. LI Z.Y., JIN Z.J., LI Q. Changes in land use and their effects on soil properties in Huixian Karst Wetland system, Pol. J. Environ. Stud. 26 (2), 699, 2017.

33. LI S.H., JIN B.X., ZHOU J.S.,WANG J.L., PENG S.Y. Analysis of the spatiotemporal land-use/land-cover change and its driving forces in Fuxian lake watershed, 1974 to 2014, Pol. J. Environ. Stud. 26 (2), 671, 2017.

34. WANG Y. The Application Research of Constrained LESA Model in Well-facilitated Capital Farmland Construction Area Planning: A Case Study of Guangxi, Guiping city. Nanning: Guangxi Teachers Education University, 2014 [In China]. 